Article

\title{
Nitrogen Sources and Rates Affect Soybean Seed Composition in Mississippi
}

\author{
Gurpreet Kaur ${ }^{1, *}$ (D), William R. Serson ${ }^{2}$, John M. Orlowski ${ }^{1}$, Justin M. McCoy ${ }^{1}$, \\ Bobby R. Golden ${ }^{1}$ and Nacer Bellaloui ${ }^{3}$ \\ 1 Delta Research and Extension Center, Mississippi State University, 82 Stoneville Road, Stoneville, MS 38776, \\ USA; jmo236@msstate.edu (J.M.O.); jmccoy@drec.msstate.edu (J.M.M.); bgolden@drec.msstate.edu (B.R.G.) \\ 2 Department of Biology, Ave Maria University, 5050 Ave Maria Blvd, Ave Maria, FL 34142, USA; \\ William.Serson@avemaria.edu \\ 3 Crop Genetics Research Unit, United States Department of Agriculture-Agricultural Research Service, \\ 141 Experiment Station Road, Stoneville, MS 38776, USA; nacer.bellaloui@ars.usda.gov \\ * Correspondence: GK340@msstate.edu; Tel.: +1-662-769-9961
}

Received: 27 September 2017; Accepted: 13 November 2017; Published: 22 November 2017

\begin{abstract}
Soybean (Glycine max L.) seed is a major source of protein, oil, carbohydrates and other nutrients that are important for human and animal nutrition. Producers have considered applying nitrogen $(\mathrm{N})$ fertilizer to soybean crop to maximize seed yield; however, its effect on seed composition is not well understood. The objective of this two-year (2015 and 2016) study was to evaluate the effects of $\mathrm{N}$ fertilizer sources and application rates $\left(45,90,135\right.$ and $179 \mathrm{~kg} \mathrm{~N} \mathrm{ha}^{-1}$ ) on soybean seed composition on two soil textures (clay and silt-loam) in Mississippi. The three fertilizer sources included in this study were urea with $\mathrm{N}$-(n butyl) thiophosphoric triamide (Urea+NBPT), polymer-coated urea (PCU), and ammonium sulfate (AMS). Nitrogen application at $179 \mathrm{~kg} \mathrm{ha}^{-1}$ on clay soil reduced seed protein by $1.05 \%$ compared to unfertilized soybeans in 2016. However, $\mathrm{N}$ application at $179 \mathrm{~kg} \mathrm{ha}^{-1}$ increased oil content by $0.7 \%$ on clay soil compared to the unfertilized soybeans only in 2016. Nitrogen applications reduced stachyose content on both soil textures in 2015. The fatty acids showed variable response to $\mathrm{N}$ applications. Since, seed quality is not a trait from which growers receive an economic incentive, they are unlikely to adopt this practice for standard soybean production.
\end{abstract}

Keywords: protein; oil; fatty acids; sugars; fiber; starch

\section{Introduction}

Soybean fulfills its nitrogen $(\mathrm{N})$ requirement mainly through symbiotic biological nitrogen fixation (BNF) or by $\mathrm{N}$ uptake from soil. On average, the BNF satisfies only $50-60 \%$ of soybean $\mathrm{N}$ demand [1] which is enough to achieve only $80-90 \%$ of soybean yield possible with $\mathrm{N}$ fertilization [2-4]. Any gap between the soybean $\mathrm{N}$ demand and $\mathrm{N}$ supply by BNF needs to be supplied by $\mathrm{N}$ uptake from other sources [5]. In an effort to provide soybeans with adequate $\mathrm{N}$ for maximum seed yield, producers have considered applying $\mathrm{N}$ fertilizer to their soybean crop. Previous studies have reported inconsistent responses of soybean seed yield to $\mathrm{N}$ fertilizer applications [6-18]. For instance, in the Southern US, no effect was reported in Texas [7] and Alabama [6]. However, Ray et al. (2006) reported an increase in soybean seed yield by $7.7 \%$ and $15.5 \%$ for irrigated and non-irrigated environments, respectively, due to a large amount of $\mathrm{N}$ applications in Mississippi [17]. McCoy (2016) reported an increase in soybean seed yield of $4 \%$ and $8 \%$ on sandy/silt loam and clay soil, respectively, due to $\mathrm{N}$ applications in Mississippi [19]. Soybean yield response to $\mathrm{N}$ applications depends upon soil properties (soil temperature, $\mathrm{pH}$, moisture, soil nitrate content at planting) $[8,13,20]$, irrigation [13] and cultivars [8]. Previous studies on $\mathrm{N}$ application effects in soybeans have examined seed yields, biomass production, 
nodulation or other plant growth parameters in the southern US [8,21,22]. However, the impact of $\mathrm{N}$ applications on soybean seed composition is not well documented.

Soybean seed is a major source of protein, oil, carbohydrates and other nutrients that are important for humans and animals. Soybean is composed of approximately $40 \%$ protein, $20 \%$ oil and $33 \%$ carbohydrates [23]. The protein and oil concentration determines the economic value of soybean seed [24]. The oil portion of the soybean seed mainly consists of saturated fatty acids (such as palmitic and stearic acid), and unsaturated fatty acids (such as oleic, linoleic, and linolenic acid) [25]. Lower palmitic acid, linoleic acid and linolenic acid, and higher oleic acid content is desirable for enhancing soybean oil shelf life and flavor stability [26]. Linoleic and linolenic acids are essential fatty acids that mammals cannot synthesize and thus, need to be supplied through their diets [27]. Soybean also contains both structural (cell wall polysaccharides such as cellulose, hemicellulose, pectins) and nonstructural carbohydrates (starch, mono-, di-, and oligosaccharides). On average, soybean seed consists of $9-12 \%$ of soluble carbohydrates such as sucrose, raffinose, and stachyose, which contributes to seed quality. Low levels of raffinose and stachyose are preferred in soybean seeds for better seed quality as these two carbohydrates cause diarrhea in non-ruminant animals. Higher sucrose levels in soybean seed improve taste and flavor of food products. Starch is a storage polysaccharide that accumulates in developing soybean seeds until 30-40 days after flowering and then, its concentration declines rapidly to $<1 \%$ at maturity [27]. Cell wall polysaccharides along with lignin, enzyme-resistant starch and oligosaccharides constitute a non-digestible part of food/feed known as dietary fiber [27]. Dietary fiber is measured using different methods including crude fiber analysis, enzymatic-gravimetric dietary fiber analysis, acid detergent fiber (ADF) or neutral detergent fiber (NDF) methods.

Protein and fatty acid synthesis occurs at different rates and times during seed development and can be affected by $\mathrm{N}$ availability during seed development and maturation period [28]. Some previous research from the southern US addresses the effect of $\mathrm{N}$ fertilizer on soybean protein and oil content $[16,22]$. Among those that did, $\mathrm{N}$ fertilization did not affect soybean seed protein and oil content in Alabama [8,22]. For studies conducted in Florida and Arkansas, Purcell and King (1996) reported a decrease in seed protein and increase in oil concentration due to $\mathrm{N}$ applications at $112 \mathrm{~kg} \mathrm{ha}^{-1}$ rate at $\mathrm{V} 6, \mathrm{R} 2$ or V6 and R2 stages [29]. In Mississippi, the impact of $\mathrm{N}$ application on soybean seed composition was only reported by Ray et al. (2006) [16] and Bellaloui et al. (2011) [30]. Ray et al. (2006) reported reduced protein concentration and increased oil concentration in both irrigated and non-irrigated environments resulting from very large applications of $\mathrm{N}$ (averaged over application rates of 290, 310 and $360 \mathrm{~kg} \mathrm{~N} \mathrm{ha}^{-1}$ ) on clay soil [16]. Bellaloui et al. (2011) found that $\mathrm{N}$ application at $112 \mathrm{~kg} \mathrm{ha}^{-1}$ in irrigated and non-irrigated soybeans in Mississippi affected protein, oil, and fatty acid composition including palmitic acid, stearic acid, oleic acid, linoleic acid and linolenic acid [30].

While these previous studies have begun to address the effect of $\mathrm{N}$ fertilizer on soybean seed composition they either only investigated a single $\mathrm{N}$ rate [30] or agronomically unrealistic $\mathrm{N}$ rates [16]. As more producers in the mid-southern US consider $\mathrm{N}$ fertilization of soybeans, information on the effect of multiple $\mathrm{N}$ rates and multiple $\mathrm{N}$ fertilizer sources on total soybean seed composition will be required. Therefore, the objective of this study was to evaluate the effect of $\mathrm{N}$ rate and $\mathrm{N}$ source on soybean seed composition including protein, oil, palmitic acid, stearic acid, oleic acid, linoleic acid, linolenic acid, fiber, starch, ash, ADF, and NDF.

\section{Materials and Methods}

Field studies were conducted at the Mississippi State University Delta Research and Extension Center in Stoneville, MS $\left(33^{\circ} 25^{\prime} \mathrm{N}, 90^{\circ} 54^{\prime} \mathrm{W}\right)$ in 2015 and 2016 on two soil textures commonly used for commercial soybean production in the Mississippi Delta. In 2015, the field experiment was conducted on a Dubbs silt-loam (fine-silty, mixed, active, thermic Typic Hapludalfs) and a Tunica clay (clayey over loamy, smectitic over mixed, superactive, nonacid, thermic Vertic Epiaquepts). The study was conducted only on a Tunica clay in 2016. 
The soybean variety 'Pioneer 49T80' was seeded into conventionally tilled plots at 333,585 seeds ha ${ }^{-1}$ on 16 April for silt-loam soil and 30 April for clay soil in 2015 . In 2016, soybean variety 'Asgrow 4632' was planted at 333,585 seeds ha ${ }^{-1}$ on 7 May. Each plot consisted of four rows of soybean spaced $100 \mathrm{~cm}$ apart. Pest management and irrigation scheduling were performed according to Mississippi State University Extension recommendations.

The experimental design was a randomized complete block arrangement with four replications. Treatments consisted of a factorial arrangement of three $\mathrm{N}$ fertilizer sources ( $\mathrm{N}$ source), and five $\mathrm{N}$ fertilizer application rates ( $\mathrm{N}$ rate). Nitrogen sources used in this study were: ammonium sulfate (AMS; 21-0-0-24S), polymer-coated urea (PCU; 44-0-0) (Environmentally Smart Nitrogen, Agrium Inc., Calgary, AB, Canada), and Urea+NBPT [N-(n butyl) thiophosphoric triamide] (46-0-0). The NBPT product used was Agrotain (Koch Agronomic Services, Wichita, KS, USA) which is a urease inhibitor that limits $\mathrm{N}$ loss from urea via a reduction in ammonia volatilization. All $\mathrm{N}$ sources were broadcast by hand to assigned plots at $\mathrm{N}$ rates of $0,45,90,135$, and $179 \mathrm{~kg} \mathrm{~N} \mathrm{ha}^{-1}$ at the $\mathrm{R} 1$ growth stage of soybean. The initial soil characterization information is provided in Table 1 and details about soil sampling and analysis is provided in McCoy (2016) [19].

Table 1. Selected soil chemical properties of research fields used for studies in Stoneville, MS in 2014 and 2015.

\begin{tabular}{|c|c|c|c|c|c|c|c|c|c|c|c|c|}
\hline \multirow{2}{*}{ Year } & \multirow{2}{*}{$\begin{array}{c}\text { Soil } \\
\text { Texture }\end{array}$} & \multirow{2}{*}{$\begin{array}{c}\text { Soil } \\
\text { Description }\end{array}$} & \multirow{2}{*}{$\begin{array}{c}\text { Soil } \\
\text { pH }\end{array}$} & \multirow{2}{*}{ O.M. ${ }^{\dagger}$} & \multirow{2}{*}{$\mathrm{CEC}^{\dagger}$} & \multicolumn{7}{|c|}{ Mehlich-3 Extractable Nutrients } \\
\hline & & & & & & $\mathbf{P}$ & $\mathbf{K}$ & $\mathrm{Ca}$ & $\mathrm{Mg}$ & $\mathrm{Na}$ & $\mathrm{S}$ & Zn \\
\hline & & & $(1: 2)$ & $\%$ & Meq $100 \mathrm{~g}^{-1}$ & \multicolumn{7}{|c|}{$\mathrm{mg} \mathrm{kg}^{-1}$} \\
\hline 2015 & Silt loam & Dubbs Silt Loam & 6.3 & 0.7 & 11.1 & 29 & 263 & 1171 & 254 & 13 & 10 & 3.5 \\
\hline 2015 & Clay & Tunica Clay & 6.8 & 1.7 & 29.7 & 105 & 421 & 4163 & 991 & 29 & 18 & 7.0 \\
\hline 2016 & Clay & Tunica Clay & 7.7 & 2.7 & 38.7 & 44 & 266 & 5445 & 1305 & 84 & 177 & 5.0 \\
\hline
\end{tabular}

Soybean was harvested from the middle two rows of each plot using a small-plot combine (Kincaid Equipment, Haven, KS, USA). A single $0.5 \mathrm{~kg}$ seed sample was collected from each plot for analysis of seed quality parameters including protein, oil, fatty acids (palmitic acid, stearic acid, oleic acid, linoleic acid, linolenic acid), fiber, starch, ash, ADF, NDF and sugars (sucrose, raffinose, and stachyose). Soybean seeds were analyzed for sugars only in 2015.

A $25 \mathrm{~g}$ soybean seed sub-sample was ground using the laboratory Mill 3600 (Perten, Springfield, IL, USA) and the protein, oil, fatty acids, sugars, acid detergent fiber (ADF) and neutral detergent fiber (NDF) were determined by near-infrared reflectance using the AD 7200 array feed analyzer (Perten, Springfield, IL, USA) [31,32]. Perten's Thermo Galactic PLS IQ software was used by the University of Minnesota for developing calibrations and a calibration curve was updated regularly according to Association of Official Analytical Chemists (AOAC) methods [30]. Seed protein, oil, fiber, starch, ash, $\mathrm{ADF}, \mathrm{NDF}$, and sugar concentrations were determined based on a seed dry matter, whereas fatty acids concentrations were determined based on total oil concentration.

Data were analyzed using the PROC MIXED procedure in SAS v9.4 (SAS Institute Inc., Cary, NC, USA). Due to differences in soil texture and soybean variety, each site-year was analyzed separately. Nitrogen source and $\mathrm{N}$ rate were considered fixed effects while replication was considered a random effect. Least square means were calculated and mean separation $(p<0.1)$ was produced using PDMIX800 in SAS (Statistical Analysis System), a macro for converting mean separation output to letter groupings [33].

\section{Results}

\subsection{Soybean Seed Composition under Silt-Loam Soil}

Soybean seed protein, oil, palmitic acid, oleic acid, stearic acid, linolenic acid, and sugars including raffinose, and sucrose concentrations (Table 2) were not affected by the $\mathrm{N}$ fertilization on the silt-loam soil in 2015. The mean concentrations for these seed composition parameters are provided in Tables 2 and 3. 
Table 2. Soybean seed protein, oil, fatty acids, starch, fiber, and ash as affected by the N application rates in 2015 and 2016.

\begin{tabular}{|c|c|c|c|c|c|c|c|c|c|c|c|c|c|c|}
\hline \multirow{2}{*}{$\begin{array}{l}\text { Soil } \\
\text { Texture }\end{array}$} & \multirow[b]{2}{*}{ Year } & \multirow[b]{2}{*}{ N Rates } & \multirow[b]{2}{*}{ Protein } & \multirow[b]{2}{*}{ Oil } & \multicolumn{5}{|c|}{ Fatty Acids } & \multirow[b]{2}{*}{ Fiber } & \multirow[b]{2}{*}{ Starch } & \multirow[b]{2}{*}{ Ash } & \multirow[b]{2}{*}{$\mathrm{ADF}$} & \multirow[b]{2}{*}{ NDF } \\
\hline & & & & & $\begin{array}{c}\text { Palmitic } \\
\text { Acid }\end{array}$ & $\begin{array}{c}\text { Stearic } \\
\text { Acid }\end{array}$ & $\begin{array}{l}\text { Oleic } \\
\text { Acid }\end{array}$ & $\begin{array}{c}\text { Linoleic } \\
\text { Acid }\end{array}$ & $\begin{array}{l}\text { Linolenic } \\
\text { Acid }\end{array}$ & & & & & \\
\hline & & $\mathrm{kg} \mathrm{Nha}^{-1}$ & & & & & & $\mathrm{~g} \mathrm{~kg}^{-1}$ & & & & & & \\
\hline \multirow{5}{*}{ Silt loam } & 2015 & 0 & $382.6 \mathrm{a}^{+}$ & $236.2 a$ & $108.0 \mathrm{a}$ & $41.9 \mathrm{a}$ & $316.4 a$ & $474.2 \mathrm{~d}$ & $61.8 \mathrm{a}$ & $63.2 \mathrm{a}$ & $82.1 \mathrm{a}$ & $58.8 \mathrm{a}$ & $120.2 b$ & $173.0 \mathrm{a}$ \\
\hline & & 45 & $396.3 a$ & $233.9 a$ & 105.1a & $40.5 \mathrm{a}$ & $299.4 a$ & 491.0ab & $62.0 \mathrm{a}$ & $59.6 \mathrm{bc}$ & $66.2 b$ & $59.1 \mathrm{a}$ & $126.1 \mathrm{a}$ & $170.5 \mathrm{a}$ \\
\hline & & 90 & $385.6 \mathrm{a}$ & $235.0 \mathrm{a}$ & $106.4 a$ & $41.5 \mathrm{a}$ & $303.7 a$ & $486.9 \mathrm{bc}$ & $62.4 \mathrm{a}$ & $62.0 \mathrm{ab}$ & $75.3 \mathrm{ab}$ & $59.2 \mathrm{a}$ & $123.2 \mathrm{ab}$ & $170.4 \mathrm{a}$ \\
\hline & & 135 & $398.4 a$ & $234.3 a$ & $103.2 \mathrm{a}$ & $39.9 a$ & $298.4 a$ & $497.8 \mathrm{a}$ & $62.3 a$ & $58.2 \mathrm{c}$ & $68.6 \mathrm{~b}$ & $59.6 a$ & $120.4 b$ & $165.0 \mathrm{~b}$ \\
\hline & & 179 & $385.0 \mathrm{a}$ & $233.7 \mathrm{a}$ & $105.9 \mathrm{a}$ & $41.6 \mathrm{a}$ & $306.7 \mathrm{a}$ & $477.7 \mathrm{~cd}$ & $61.5 \mathrm{a}$ & $62.0 \mathrm{ab}$ & $74.4 \mathrm{ab}$ & $59.6 a$ & $124.2 \mathrm{ab}$ & $170.9 a$ \\
\hline \multirow[t]{5}{*}{ Clay } & 2015 & 0 & $391.7 \mathrm{c}$ & $219.6 a$ & $115.5 a$ & $42.5 a$ & $283.6 a$ & $482.3 a$ & $75.1 \mathrm{a}$ & $62.7 \mathrm{a}$ & 77.0ab & $57.9 a$ & $132.3 a$ & $172.8 \mathrm{a}$ \\
\hline & & 45 & $394.1 \mathrm{abc}$ & $219.6 a$ & $113.9 a$ & $41.4 \mathrm{a}$ & $289.6 a$ & $480.1 \mathrm{a}$ & $73.2 \mathrm{ab}$ & $61.8 \mathrm{a}$ & $75.2 \mathrm{ab}$ & $58.0 \mathrm{a}$ & 131.1a & $167.8 \mathrm{a}$ \\
\hline & & 90 & $401.8 \mathrm{a}$ & $217.4 a$ & $112.9 a$ & $41.7 \mathrm{a}$ & $292.6 a$ & $479.4 a$ & $71.2 \mathrm{~b}$ & $62.0 \mathrm{a}$ & $68.2 \mathrm{c}$ & $58.2 \mathrm{a}$ & $135.1 \mathrm{a}$ & $170.5 \mathrm{a}$ \\
\hline & & 135 & $398.9 \mathrm{ab}$ & $217.2 a$ & $114.2 \mathrm{a}$ & $41.8 \mathrm{a}$ & $288.1 \mathrm{a}$ & $481.4 a$ & $70.9 \mathrm{~b}$ & $61.9 \mathrm{a}$ & $72.1 \mathrm{bc}$ & $57.9 \mathrm{a}$ & $135.1 \mathrm{a}$ & $169.6 \mathrm{a}$ \\
\hline & & 179 & $394.1 b c$ & $218.8 \mathrm{a}$ & $114.2 \mathrm{a}$ & $42.3 a$ & $294.9 \mathrm{a}$ & $474.7 \mathrm{a}$ & $74.5 \mathrm{a}$ & $61.6 \mathrm{a}$ & $79.4 \mathrm{a}$ & $58.6 \mathrm{a}$ & $133.1 \mathrm{a}$ & $169.7 \mathrm{a}$ \\
\hline \multirow[t]{5}{*}{ Clay } & 2016 & 0 & $402.9 \mathrm{ab}$ & $214.9 \mathrm{~b}$ & $111.2 \mathrm{a}$ & $44.0 \mathrm{bc}$ & $238.4 a$ & $514.0 \mathrm{a}$ & $73.8 \mathrm{a}$ & $58.1 \mathrm{a}$ & $61.8 \mathrm{a}$ & $54.9 c$ & $145.1 \mathrm{a}$ & $165.9 a$ \\
\hline & & 45 & $403.4 a$ & $213.2 \mathrm{c}$ & $112.5 \mathrm{a}$ & $45.4 \mathrm{a}$ & $239.0 \mathrm{a}$ & $506.5 a$ & $74.6 \mathrm{a}$ & $59.1 \mathrm{a}$ & $61.8 \mathrm{a}$ & $55.4 \mathrm{a}$ & $145.5 a$ & $166.6 \mathrm{a}$ \\
\hline & & 90 & $400.6 b c$ & $215.5 \mathrm{ab}$ & $111.8 \mathrm{a}$ & $43.5 c$ & $236.3 a$ & 513.3a & $73.3 a$ & $59.0 \mathrm{a}$ & $63.6 a$ & $55.1 \mathrm{bc}$ & $144.8 \mathrm{a}$ & $166.4 \mathrm{a}$ \\
\hline & & 135 & $401.8 \mathrm{ab}$ & $215.2 \mathrm{ab}$ & $111.2 \mathrm{a}$ & $45.1 \mathrm{ab}$ & $234.4 a$ & $511.4 a$ & $74.0 \mathrm{a}$ & $58.5 \mathrm{a}$ & $64.1 \mathrm{a}$ & $55.3 \mathrm{ab}$ & $144.0 \mathrm{a}$ & $166.9 a$ \\
\hline & & 179 & $398.7 \mathrm{C}$ & $216.3 a$ & $111.0 \mathrm{a}$ & $44.7 \mathrm{ab}$ & $230.8 \mathrm{a}$ & $514.0 \mathrm{a}$ & $74.7 \mathrm{a}$ & $59.2 \mathrm{a}$ & $64.7 \mathrm{a}$ & $55.2 \mathrm{abc}$ & $145.8 \mathrm{a}$ & $166.1 \mathrm{a}$ \\
\hline
\end{tabular}

${ }^{\dagger}$ Same letters within a column for each soil type indicates no significant differences between means at $p<0.1$. ADF, acid detergent fiber; NDF, neutral detergent fiber. 
Table 3. Soybean seed sugars including raffinose, stachyose and sucrose as affected by the $\mathrm{N}$ application rates in 2015.

\begin{tabular}{ccccc}
\hline Soil Texture & N Rate & Raffinose & Stachyose & Sucrose \\
\hline & $\mathbf{k g ~ N ~ h a}^{\mathbf{- 1}}$ & & $\mathbf{g ~ k g}^{\mathbf{- 1}}$ & \\
\hline Silt loam & 0 & $7.1 \mathrm{a}^{\dagger}$ & $27.4 \mathrm{a}$ & $20.9 \mathrm{a}$ \\
& 45 & $6.7 \mathrm{a}$ & $24.3 \mathrm{bc}$ & $18.2 \mathrm{a}$ \\
& 90 & $7.0 \mathrm{a}$ & $26.4 \mathrm{ab}$ & $21.6 \mathrm{a}$ \\
& 135 & $7.1 \mathrm{a}$ & $24.0 \mathrm{bc}$ & $19.1 \mathrm{a}$ \\
& 179 & $7.4 \mathrm{a}$ & $22.1 \mathrm{c}$ & $23.3 \mathrm{a}$ \\
\hline Clay & 0 & $7.2 \mathrm{a}$ & $28.0 \mathrm{a}$ & $34.0 \mathrm{a}$ \\
& 45 & $7.1 \mathrm{a}$ & $25.7 \mathrm{ab}$ & $31.8 \mathrm{a}$ \\
& 90 & $6.9 \mathrm{a}$ & $23.6 \mathrm{~b}$ & $29.1 \mathrm{a}$ \\
& 135 & $6.8 \mathrm{a}$ & $23.4 \mathrm{~b}$ & $29.7 \mathrm{a}$ \\
& 179 & $6.9 \mathrm{a}$ & $24.0 \mathrm{~b}$ & $30.7 \mathrm{a}$ \\
\hline
\end{tabular}

${ }^{\dagger}$ Same letters within a column for each soil type indicates no significant differences between means at $p<0.1$.

Nitrogen application rates affected linoleic acid, fiber starch, ADF, NDF and stachyose sugar concentrations on the silt-loam soil in 2015 (Tables 2 and 3). The $\mathrm{N}$ application up to a rate of $135 \mathrm{~kg} \mathrm{ha}^{-1}$ increased linoleic acid concentration compared to unfertilized soybeans by 2.7 to $5 \%$ (Table 2). However, $\mathrm{N}$ application at $179 \mathrm{~kg} \mathrm{ha}^{-1}$ had a linoleic concentration similar to that from unfertilized soybeans. Increasing $\mathrm{N}$ application rate from 90 to $135 \mathrm{~kg} \mathrm{ha}^{-1}$ increased linoleic acid concentration by $2.2 \%$.

Nitrogen application at 90 and $179 \mathrm{~kg} \mathrm{ha}^{-1}$ rate caused no change in fiber and starch content of soybean seed compared to unfertilized soybean. However, the $\mathrm{N}$ application at 45 and $135 \mathrm{~kg} \mathrm{ha}^{-1}$ rates reduced fiber concentration by $5.8 \%$ and $8 \%$, respectively, compared to unfertilized soybeans. Similar to fiber concentration, $\mathrm{N}$ application at 45 and $135 \mathrm{~kg} \mathrm{~N} \mathrm{ha}^{-1}$ rate reduced starch concentration compared to unfertilized soybean by $19 \%$ and $16.5 \%$, respectively. Nitrogen application at $45 \mathrm{~kg} \mathrm{~N} \mathrm{ha}^{-1}$ resulted in 5\% higher ADF content than the unfertilized soybeans. Any further increase in $\mathrm{N}$ application rate did not result in any increase in ADF compared to unfertilized soybeans. The NDF concentration in soybean seed was significantly lower with $135 \mathrm{~kg} \mathrm{~N} \mathrm{ha}^{-1}$ compared to other $\mathrm{N}$ application rates and unfertilized soybean.

Application of $\mathrm{N}$ at 135 and $179 \mathrm{~kg} \mathrm{~N}$ ha $^{-1}$ reduced stachyose sugar content in soybean seed compared to unfertilized soybean (Table 3). Seed oil and stachyose sugar content was affected by $\mathrm{N}$ source on the silt-loam soil in 2015 (Table 4). Using AMS as the N source resulted in a 2\% increase of seed oil concentration compared to PCU and Urea+NBPT. Seed stachyose concentration was $15 \%$ and $10 \%$ higher when AMS was used as the N source compared to PCU and Urea+NBPT, respectively.

Table 4. Soybean seed oil and stachyose sugar concentration as affected by the $\mathrm{N}$ sources on silt-loam soil in 2015.

\begin{tabular}{ccc}
\hline N Source & Oil & Stachyose \\
\hline & $\mathbf{g ~ k g}^{-\mathbf{1}}$ & $\mathbf{g ~ k g}^{\mathbf{- 1}}$ \\
\hline AMS & $237.7 \mathrm{a}{ }^{+}$ & $26.9 \mathrm{a}$ \\
PCU & $233.1 \mathrm{~b}$ & $23.5 \mathrm{~b}$ \\
Urea+NBPT & $233.1 \mathrm{~b}$ & $24.3 \mathrm{~b}$ \\
\hline
\end{tabular}

+ Same letters within a column indicates no significant differences between means at $p<0.1$. Urea+NBPT, [N-(n butyl) thiophosphoric triamide]; PCU polymer-coated urea, AMS ammonium sulfate. 


\subsection{Soybean Seed Composition under Clay Soil}

\subsubsection{Seed Composition in 2015}

In 2015, the $\mathrm{N}$ application rates affected only protein, linolenic acid, starch, and stachyose sugar concentration on clay soil (Table 2). Application of 90 and $135 \mathrm{~kg} \mathrm{~N} \mathrm{ha}^{-1}$ increased protein concentration by $2.6 \%$ and $1.8 \%$ compared to the unfertilized soybean. However, protein concentration was not increased significantly compared to unfertilized soybean when $\mathrm{N}$ was applied at either 45 or $179 \mathrm{~kg} \mathrm{ha}^{-1}$. No differences were found for protein concentration between $\mathrm{N}$ rates of 45, 90 and $135 \mathrm{~kg} \mathrm{~N} \mathrm{ha}^{-1}$ as well as between 135 and $179 \mathrm{~kg} \mathrm{~N} \mathrm{ha}^{-1}$ on clay soil in 2015 . No clear trends were obtained for the protein concentration on clay soil in 2015 due to $\mathrm{N}$ applications.

Application of $45 \mathrm{~kg} \mathrm{~N} \mathrm{ha}^{-1}$ did not cause any change in linolenic acid concentration on clay soil in 2015 compared to unfertilized soybean (Table 2). Further increasing $\mathrm{N}$ rate to 90 and $135 \mathrm{~kg} \mathrm{~N} \mathrm{ha}^{-1}$ reduced linolenic acid concentration by $5.2 \%$ and $5.5 \%$ compared to unfertilized soybeans.

Starch concentration with 90 and $135 \mathrm{~kg} \mathrm{~N} \mathrm{ha}^{-1}$ was $14 \%$ and $9 \%$ lower compared to $\mathrm{N}$ application at $179 \mathrm{~kg} \mathrm{ha}^{-1}$. Application of $45 \mathrm{~kg} \mathrm{~N} \mathrm{ha}^{-1}$ did not cause any change in stachyose concentration compared to unfertilized soybeans on clay soil in 2015 (Table 3). However, $\mathrm{N}$ application at 90, 135 and $179 \mathrm{~kg} \mathrm{~N} \mathrm{ha}^{-1}$ reduced stachyose sugar by $14 \%$ to $16 \%$ compared to unfertilized soybean.

\subsubsection{Seed Composition in 2016}

Nitrogen fertilization in soybeans on clay soil in 2016 did not affect palmitic acid, oleic acid, linolenic acid, fiber, starch, ADF, NDF, raffinose, stachyose and sucrose (Table 2).

In 2016, $\mathrm{N}$ application at $179 \mathrm{~kg} \mathrm{ha}^{-1}$ on clay soil reduced seed protein concentration by $1.05 \%$ compared to unfertilized soybeans (Table 2). The protein concentration from unfertilized soybeans was similar to $\mathrm{N}$ application rates of 45,90 and $135 \mathrm{~kg} \mathrm{ha}^{-1}$. The seed oil concentration was increased by $0.7 \%$ and $1.4 \%$ due to $\mathrm{N}$ application at $179 \mathrm{~kg} \mathrm{ha}^{-1}$ compared to unfertilized soybeans and $\mathrm{N}$ application rate of $45 \mathrm{~kg} \mathrm{ha}^{-1}$ (Table 2). No differences were found between $\mathrm{N}$ application rates of 90, 135 and $179 \mathrm{~kg} \mathrm{~N} \mathrm{ha}^{-1}$ for seed oil concentration on clay soil in 2016. Stearic acid concentration was $3.2 \%$ and $4.2 \%$ higher with $\mathrm{N}$ application at $45 \mathrm{~kg} \mathrm{ha}^{-1}$ than unfertilized soybeans and $90 \mathrm{~kg} \mathrm{~N} \mathrm{ha}^{-1}$, respectively.

When AMS was used as $\mathrm{N}$ source, the linoleic acid concentration was $10-15.5 \mathrm{~g} \mathrm{~kg}^{-1}$ less for $\mathrm{N}$ application rate of $135 \mathrm{~kg} \mathrm{ha}^{-1}$ compared to unfertilized soybeans and $\mathrm{N}$ application at 90 and $179 \mathrm{~kg} \mathrm{ha}^{-1}$ (Table 5). Linoleic acid was reduced by $13-14 \mathrm{~g} \mathrm{~kg}^{-1}$ due to $\mathrm{N}$ application at $45 \mathrm{~kg} \mathrm{ha}^{-1}$ than for 135 and $179 \mathrm{~kg} \mathrm{~N}^{-1}$ using PCU as N source. Urea+NBPT application at $45 \mathrm{~kg} \mathrm{ha}^{-1}$ had $11.6 \mathrm{~g} \mathrm{~kg}^{-1}$ less linoleic acid concentration than unfertilized soybeans.

Table 5. Soybean seed linoleic acid and ash concentration as affected by the $\mathrm{N}$ source and $\mathrm{N}$ rate for study conducted on clay soil in 2016.

\begin{tabular}{cccc}
\hline N Source & N Application Rate & Linoleic Acid & Ash \\
\hline \multirow{2}{*}{ AMS ha $^{\mathbf{- 1}}$} & \multicolumn{2}{c}{$\mathbf{g ~ k g}^{\mathbf{- 1}}$} \\
& 0 & $514.0 \mathrm{ab}{ }^{+}$ & $54.9 \mathrm{de}$ \\
& 45 & $512.2 \mathrm{abc}$ & $54.9 \mathrm{de}$ \\
90 & $519.5 \mathrm{a}$ & $54.7 \mathrm{e}$ \\
& 135 & $504.0 \mathrm{c}$ & $55.6 \mathrm{ab}$ \\
& 179 & $518.8 \mathrm{a}$ & $55.1 \mathrm{bcde}$ \\
\hline PCU & 0 & $514.0 \mathrm{ab}$ & $54.9 \mathrm{de}$ \\
& 45 & $504.8 \mathrm{bc}$ & $56.0 \mathrm{a}$ \\
& 90 & $510.0 \mathrm{abc}$ & $55.5 \mathrm{ab}$ \\
& 135 & $519.0 \mathrm{a}$ & $54.9 \mathrm{de}$ \\
& 179 & $517.8 \mathrm{a}$ & $55.2 \mathrm{bcde}$ \\
\hline
\end{tabular}


Table 5. Cont.

\begin{tabular}{cccc}
\hline N Source & N Application Rate & Linoleic Acid & Ash \\
\hline Urea+NBPT & $\mathbf{k g ~ N ~ h a}^{\mathbf{- 1}}$ & \multicolumn{2}{c}{$\mathbf{g ~ k g}^{-\mathbf{1}}$} \\
& 0 & $514.0 \mathrm{ab}$ & $54.9 \mathrm{de}$ \\
& 45 & $502.4 \mathrm{c}$ & $55.4 \mathrm{bcd}$ \\
90 & $510.4 \mathrm{abc}$ & $55.0 \mathrm{cde}$ \\
& 135 & $511.3 \mathrm{abc}$ & $55.5 \mathrm{abc}$ \\
& 179 & $505.3 \mathrm{bc}$ & $55.3 \mathrm{bcde}$ \\
\hline
\end{tabular}

${ }^{+}$Same letters within a column indicates no significant differences between means at $p<0.1$. AMS, ammonium sulfate; PCU, polymer coated urea; NBPT, [N-(n butyl) thiophosphoric triamide].

\section{Discussion}

For studies conducted in Mississippi, soybean seed composition showed inconsistent responses to $\mathrm{N}$ fertilization between soil textures and years, probably due to differences in environmental conditions during the growing season [34-36], soil properties [35], soybean varieties, and/or crop management practices such as planting dates, tillage, fertility, and plant density [37]. Climatic conditions such as lower temperatures and higher precipitation amounts during seed filling may reduce protein and oil concentration, whereas high air temperatures and moderate rainfall at the seed filling period can result in higher protein concentration in soybean seeds [35,38]. In general, $\mathrm{N}$ sources performed similarly and did not show differences for most of the seed composition parameters measured in our study, in agreement with findings from other studies [15]. McCoy (2016) reported that belowground biomass, root length, root area, root diameter and nodule numbers were significantly lower for clay soil compared to silt-loam soil, which possibly affected biological nitrogen fixation and consequently, soybean response to $\mathrm{N}$ fertilizer applications [19].

The decrease in protein concentration with $\mathrm{N}$ application at $179 \mathrm{~kg} \mathrm{ha}^{-1}$ was only observed on clay soil in one out of two years of study. Increase in oil concentrations due to $\mathrm{N}$ applications occurred on clay soil in 2016, whereas no changes occur in oil concentration in 2015. Nitrogen fertilization did not change seed protein concentration on silt-loam soil in 2015. Previous studies have shown that protein and oil concentrations were negatively correlated resulting in the opposite trend for soybean seed protein and oil concentration in response to $\mathrm{N}$ applications in our study on clay soil [16]. In agreement with our results, multiple studies have also reported inconsistent responses of soybean seed protein and oil content to $\mathrm{N}$ applications [10,15,16,39-42]. In Arkansas, $112 \mathrm{~kg} \mathrm{~N}$ ha $^{-1}$ when applied at the $\mathrm{R} 2$ growth stage in soybeans caused no changes in seed protein and oil concentration compared to unfertilized soybeans on silt loam soil [40]. Wesley et al. (1998) found an increase in protein and oil content by $1 \%$ and $0.3-0.5 \%$ because of $\mathrm{N}$ applications at R3-R4 stage at rates of 22 and $44 \mathrm{~kg} \mathrm{ha}^{-1} \mathrm{using}$ multiple $\mathrm{N}$ sources at some of the locations in Kansas, however, $\mathrm{N}$ applications showed inconsistent and overall no significant effects on seed protein and oil content, when combined over multiple locations [10]. A study in Minnesota showed $\mathrm{N}$ application at $84 \mathrm{~kg} \mathrm{ha}^{-1}$ increased protein content by $0.4 \mathrm{~g} \mathrm{~kg}^{-1}$ and showed no change in oil content when averaged over $\mathrm{N}$ application timing, methods and sources [12]. Particularly in Mississippi State, the protein concentration of irrigated soybeans decreased by $2.7 \%$ and oil concentration was increased by $2.2 \%$ when a large amount of $\mathrm{N}$ was applied at 290, 310 and $360 \mathrm{~kg} \mathrm{ha}^{-1}$ at planting on the Sharkey clay soil [16]. Another study in the Mississippi Delta region found that $\mathrm{N}$ application at $112 \mathrm{~kg} \mathrm{ha}^{-1}$ at V3-V4 growth stage reduced protein content and increased oil content only in one out of two years of study on silty clay loam soil [30].

Palmitic acid, oleic acid, raffinose and sucrose sugar showed no response to $\mathrm{N}$ fertilization in the two years of this study. Stearic acid, and linoleic acid concentrations showed a variable response to $\mathrm{N}$ fertilization in the two years of this study. Similarly, stearic acid, oleic acid, and linoleic acid concentrations, averaged over two years, were increased by $0.85,7.5$, and $16.1 \mathrm{~g} \mathrm{~kg}^{-1}$ when $112 \mathrm{~kg} \mathrm{~N} \mathrm{ha}^{-1}$ was applied at the V3-V4 growth stage of soybean on silty clay loam soil in Mississippi [30]. However, the same study reported that linolenic acid concentration was reduced by 
$6.2 \mathrm{~g} \mathrm{~kg}^{-1}$ in the first year and increased in another year by $10.8 \mathrm{~g} \mathrm{~kg}^{-1}$ due to $\mathrm{N}$ applications [30]. No changes in fatty acids content due to $\mathrm{N}$ applications was observed by Ham et al. (1975) and Bennett and Krishnan (2005) [35,39]. Ham et al. (1975) found that fatty acids including palmitic acid, stearic acid, oleic acid, linoleic acid and linolenic acid did not change with pre-plant $\mathrm{N}$ application at $224 \mathrm{~kg} \mathrm{ha}^{-1}$ in Minnesota [39].

Linolenic acid, fiber, starch, ash, NDF and ADF concentrations showed variable response to N application rates in all study years and soil textures. Similarly, Howell and Collins (1957) reported that linoleic and linolenic acid levels were inversely correlated with temperature and little or not affected by N, P, K and S nutrition, the addition of manure/plant residues [43]. Seed fiber content, ADF and NDF were affected by $\mathrm{N}$ rate only on silt loam soil. Barker and Sawyer (2005) found that fiber concentration in soybean seeds remained unchanged when $\mathrm{N}$ was applied at 45 and $90 \mathrm{~kg} \mathrm{ha}^{-1}$ during reproductive stages [15].

\section{Conclusions}

In this study, the impacts of nitrogenous fertilizer application were examined with regards to its impact on seed composition. Ammonium sulfate (AMS; 21-0-0-24S), polymer-coated urea (PCU; 44-0-0), and Urea+NBPT [N-(n butyl) thiophosphoric triamide] (46-0-0) were applied at rates of 0 , $45,90,135$, and $179 \mathrm{~kg} \mathrm{~N} \mathrm{ha}^{-1}$ at the R1 growth stage of soybean. Although there was an increase of oil in one out of two years of study on clay soil at the rate of $179 \mathrm{~kg} \mathrm{ha}^{-1}$ regardless of its source, inconsistent responses of some seed composition components including protein, fiber, sugars and fatty acids were also found. The responses of seed composition constituents were different, depending on soil type, the rate of application, and location. The response of seed composition due to the nitrogenous application has also shown to be inconsistent in previous studies. Further, economic analysis for our study showed that $\mathrm{N}$ application is not an economically feasible option for increasing soybean yield as net returns with $\mathrm{N}$ application at any rate was lower than the unfertilized soybeans for both soil types (unpublished data) [44]. Since there is no economic incentive to growers for seed oil or protein at the grain elevator, it is unlikely that $\mathrm{N}$ fertilizer will be adopted strictly for increasing seed composition constituents as yield is the main determinant factor for profit.

Acknowledgments: This publication is a contribution of the Mississippi Agricultural and Forestry Experiment Station. This work was funded by the Mississippi Soybean Promotion Board and the U.S. Department of Agriculture, Agricultural Research Service Project 6066-21220-012-00D. Mention of trade names or commercial products in this publication is solely for the purpose of providing specific information and does not imply recommendation or endorsement by the U.S. Department of Agriculture. USDA is an equal opportunity provider and employer.

Author Contributions: J.M. Orlowski, B.R. Golden and J.M. McCoy designed the experiments and collected data; G. Kaur and J.M. McCoy analyzed the data; N. Bellaloui contributed analysis tools; all authors were involved with manuscript preparation and editing.

Conflicts of Interest: The authors declare no conflict of interest.

\section{References}

1. Salvagiotti, F.; Cassman, K.G.; Specht, J.E.; Walters, D.T.; Weiss, A.; Dobermann, A. Nitrogen uptake, fixation and response to fertilizer $\mathrm{n}$ in soybeans: A review. Field Crops Res. 2008, 108, 1-13. [CrossRef]

2. Silsbury, J. Energy requirement for symbiotic nitrogen fixation. Nature 1977, 267, 149-150. [CrossRef] [PubMed]

3. Ryle, G.; Powell, C.; Gordon, A. The respiratory costs of nitrogen fixation in soyabean, cowpea, and white clover ii. Comparisons of the cost of nitrogen fixation and the utilization of combined nitrogen. J. Exp. Bot. 1979, 30, 145-153. [CrossRef]

4. Thies, J.E.; Singleton, P.W.; Bohlool, B.B. Influence of the size of indigenous rhizobial populations on establishment and symbiotic performance of introduced rhizobia on field-grown legumes. Appl. Environ. Microbiol. 1991, 57, 19-28. [PubMed] 
5. Zapata, F.; Danso, S.; Hardarson, G.; Fried, M. Time course of nitrogen fixation in field-grown soybean using nitrogen-15 methodology. Agron. J. 1987, 79, 172-176. [CrossRef]

6. Terman, G. Yields and nutrient accumulation by determinate soybeans, as affected by applied nutrients. Agron. J. 1977, 69, 234-238. [CrossRef]

7. Sij, J.; Turner, F.; Craigmiles, J. "Starter nitrogen”; fertilization in soybean culture 1. Commun. Soil Sci. Plant Anal. 1979, 10, 1451-1457. [CrossRef]

8. Wood, C.; Torbert, H.; Weaver, D. Nitrogen fertilizer effects on soybean growth, yield, and seed composition. J. Prod. Agric. 1993, 6, 354-360. [CrossRef]

9. Starling, M.E.; Wood, C.; Weaver, D.B. Starter nitrogen and growth habit effects on late-planted soybean. Agron. J. 1998, 90, 658-662. [CrossRef]

10. Wesley, T.; Lamond, R.; Martin, V.; Duncan, S. Effects of late-season nitrogen fertilizer on irrigated soybean yield and composition. J. Prod. Agric. 1998, 11, 331-336. [CrossRef]

11. Freeborn, J.R.; Holshouser, D.L.; Alley, M.M.; Powell, N.L.; Orcutt, D.M. Soybean yield response to reproductive stage soil-applied nitrogen and foliar-applied boron. Agron. J. 2001, 93, 1200-1209. [CrossRef]

12. Schmitt, M.A.; Lamb, J.A.; Randall, G.W.; Orf, J.H.; Rehm, G.W. In-season fertilizer nitrogen applications for soybean in minnesota. Agron. J. 2001, 93, 983-988. [CrossRef]

13. Scharf, P.C.; Wiebold, W.J. Soybean yield responds minimally to nitrogen applications in missouri. Crop Manag. 2003, 2. [CrossRef]

14. Gutiérrez-Boem, F.H.; Scheiner, J.D.; Rimski-Korsakov, H.; Lavado, R.S. Late season nitrogen fertilization of soybeans: Effects on leaf senescence, yield and environment. Nutr. Cycl. Agroecosyst. 2004, 68, 109-115. [CrossRef]

15. Barker, D.W.; Sawyer, J.E. Nitrogen application to soybean at early reproductive development. Agron. J. 2005, 97, 615-619. [CrossRef]

16. Ray, J.; Fritschi, F.; Heatherly, L. Large applications of fertilizer $\mathrm{n}$ at planting affects seed protein and oil concentration and yield in the early soybean production system. Field Crops Res. 2006, 99, 67-74. [CrossRef]

17. Ray, J.D.; Heatherly, L.G.; Fritschi, F.B. Influence of large amounts of nitrogen on nonirrigated and irrigated soybean. Crop Sci. 2006, 46, 52-60. [CrossRef]

18. Salvagiotti, F.; Specht, J.E.; Cassman, K.G.; Walters, D.T.; Weiss, A.; Dobermann, A. Growth and nitrogen fixation in high-yielding soybean: Impact of nitrogen fertilization. Agron. J. 2009, 101, 958-970. [CrossRef]

19. McCoy, J.M. Soybean Yield and Biomass Response to Supplemental Nitrogen Fertilization. Master's Thesis, Mississippi State University, Starkville, MS, USA, 2016.

20. Sorensen, R.; Penas, E. Nitrogen fertilization of soybeans. Agron. J. 1978, 70, 213-216. [CrossRef]

21. Heatherly, L.G.; Spurlock, S.R.; Reddy, K.N. Influence of early-season nitrogen and weed management on irrigated and nonirrigated glyphosate-resistant and susceptible soybean. Agron. J. 2003, 95, 446-453. [CrossRef]

22. Taylor, R.S.; Weaver, D.B.; Wood, C.; van Santen, E. Nitrogen application increases yield and early dry matter accumulation in late-planted soybean. Crop Sci. 2005, 45, 854-858. [CrossRef]

23. Hymowitz, T.; Collins, F.I. Variability of sugar content in seed of glycine max (1.) merrill and g. Soja sieb. and zucc. Agron. J. 1974, 66, 239-240. [CrossRef]

24. Rotundo, J.L.; Westgate, M.E. Meta-analysis of environmental effects on soybean seed composition. Field Crops Res. 2009, 110, 147-156. [CrossRef]

25. Bellaloui, N.; Smith, J.R.; Mengistu, A.; Ray, J.D.; Gillen, A.M. Evaluation of exotically-derived soybean breeding lines for seed yield, germination, damage, and composition under dryland production in the midsouthern USA. Front. Plant Sci. 2017, 8. [CrossRef] [PubMed]

26. Bellaloui, N.; Reddy, K.N.; Gillen, A.M.; Fisher, D.K.; Mengistu, A. Influence of planting date on seed protein, oil, sugars, minerals, and nitrogen metabolism in soybean under irrigated and non-irrigated environments. Am. J. Plant Sci. 2011, 2, 702-715. [CrossRef]

27. Medic, J.; Atkinson, C.; Hurburgh, C.R., Jr. Current knowledge in soybean composition. J. Am. Oil Chem. Soc. 2014, 91, 363-384. [CrossRef]

28. Blumenthal, J.; Baltensperger, D.; Cassman, K.G.; Mason, S.; Pavlista, A. Importance and effect of nitrogen on crop quality and health. In Nitrogen in the Environment: Sources, Problems, and Management, 2nd ed.; Elsevier: Oxford, UK, 2008; pp. 51-70. 
29. Purcell, L.C.; King, C.A. Drought and nitrogen source effects on nitrogen nutrition, seed growth, and yield in soybean. J. Plant Nutr. 1996, 19, 969-993. [CrossRef]

30. Bellaloui, N.; Ebelhar, M.W.; Gillen, A.M.; Fisher, D.K.; Abbas, H.K.; Mengistu, A.; Reddy, K.N.; Paris, R.L. Soybean seed protein, oil, and fatty acids are altered by $\mathrm{s}$ and $\mathrm{s}+\mathrm{n}$ fertilizers under irrigated or non-irrigated environments. Agric. Sci. 2011, 2, 465-476. [CrossRef]

31. Bellaloui, N.; Mengistu, A.; Kassem, M.A.; Abel, C.A.; Zobiole, L. Role of boron nutrient in nodules growth and nitrogen fixation in soybean genotypes under water stress conditions. In Advances in Biology and Ecology of Nitrogen Fixation; InTech: London, UK, 2014.

32. Bellaloui, N.; Bruns, H.A.; Abbas, H.K.; Mengistu, A.; Fisher, D.K.; Reddy, K.N. Effects of row-type, row-spacing, seeding rate, soil-type, and cultivar differences on soybean seed nutrition under us mississippi delta conditions. PLoS ONE 2015, 10, e0129913. [CrossRef] [PubMed]

33. Saxton, A. A macro for converting mean separation output to letter groupings in proc mixed. In Proceedings of the 23rd SAS Users Group International, Nashville, TN, USA, 22-25 March 1998; pp. 1243-1246.

34. Yaklich, R.; Vinyard, B.; Camp, M.; Douglass, S. Analysis of seed protein and oil from soybean northern and southern region uniform tests. Crop Sci. 2002, 42, 1504-1515. [CrossRef]

35. Bennett, J.O.; Krishnan, H.B. Long-term study of weather effects on soybean seed composition. Korean J. Crop Sci. 2005, 50, 32-38.

36. Bellaloui, N.; Smith, J.; Gillen, A.; Ray, J. Effect of maturity on seed sugars as measured on near-isogenic soybean (Glycine max) lines. Crop Sci. 2010, 50, 1978-1987. [CrossRef]

37. Yin, X.; Vyn, T.J. Relationships of isoflavone, oil, and protein in seed with yield of soybean. Agron. J. 2005, 97, 1314-1321. [CrossRef]

38. Vollmann, J.; Fritz, C.N.; Wagentristl, H.; Ruckenbauer, P. Environmental and genetic variation of soybean seed protein content under central european growing conditions. J. Sci. Food Agric. 2000, 80, 1300-1306. [CrossRef]

39. Ham, G.; Liener, I.; Evans, S.; Frazier, R.; Nelson, W. Yield and composition of soybean seed as affected by $\mathrm{n}$ and s fertilization. Agron. J. 1975, 67, 293-297. [CrossRef]

40. Purcell, L.C.; Serraj, R.; Sinclair, T.R.; De, A. Soybean $\mathrm{n}$ fixation estimates, ureide concentration, and yield responses to drought. Crop Sci. 2004, 44, 484-492. [CrossRef]

41. Osborne, S.; Riedell, W. Starter nitrogen fertilizer impact on soybean yield and quality in the northern great plains. Agron. J. 2006, 98, 1569-1574. [CrossRef]

42. Moreira, A.; Moraes, L.; Schroth, G.; Becker, F.; Mandarino, J. Soybean yield and nutritional status response to nitrogen sources and rates of foliar fertilization. Agron. J. 2017, 109, 629-635. [CrossRef]

43. Howell, R.W.; Collins, F. Factors affecting linolenic and linoleic acid content of soybean oil. Agron. J. 1957, 49, 593-597. [CrossRef]

44. McCoy, J.M.; Kaur, G.; Golden, B.R.; Orlowski, J.M.; Cook, D.; Bond, J.A.; Cox, M.S. Nitrogen fertilization of soybeans in Mississippi increases seed yield but not profitability. Agron. J. 2017, in review.

(C) 2017 by the authors. Licensee MDPI, Basel, Switzerland. This article is an open access article distributed under the terms and conditions of the Creative Commons Attribution (CC BY) license (http://creativecommons.org/licenses/by/4.0/). 